\title{
biomolecules
}

ISSN 2218-273X

www.mdpi.com/journal/biomolecules/

Review

\section{Regulation of AU-Rich Element RNA Binding Proteins by Phosphorylation and the Prolyl Isomerase Pin1}

\author{
Zhong-Jian Shen * and James S. Malter * \\ Department of Pathology, University of Texas Southwestern Medical Center, Dallas, TX 75390-8548, USA \\ * Author to whom correspondence should be addressed; E-Mails: Zhong.Shen@UTsouthwestern.edu \\ (Z.J.S.); James.Malter@UTsouthwestern.edu (J.S.M.); Tel.: +1-214-647-1266 (Z.J.S.).
}

Academic Editor: André P. Gerber

Received: 4 March 2015 / Accepted: 31 March 2015 / Published: 14 April 2015

\begin{abstract}
The accumulation of 3' untranslated region (3'-UTR), AU-rich element (ARE) containing mRNAs, are predominantly controlled at the post-transcriptional level. Regulation appears to rely on a variable and dynamic interaction between mRNA target and ARE-specific binding proteins (AUBPs). The AUBP-ARE mRNA recognition is directed by multiple intracellular signals that are predominantly targeted at the AUBPs. These include (but are unlikely limited to) methylation, acetylation, phosphorylation, ubiquitination and isomerization. These regulatory events ultimately affect ARE mRNA location, abundance, translation and stability. In this review, we describe recent advances in our understanding of phosphorylation and its impact on conformation of the AUBPs, interaction with ARE mRNAs and highlight the role of Pin1 mediated prolyl cis-trans isomerization in these biological process.
\end{abstract}

Keywords: AU-rich element; phosphorylation; prolyl isomerase Pin1; RNA-binding protein; signaling; gene regulation; mRNA turnover; kinase

\section{Introduction}

The cytoplasmic level of all mRNAs is dictated by a complex interplay between the rates of gene transcription and mRNA decay. mRNA decay allows cells to eliminate aberrant/mutant messages (nonsense-mediated) as well as modulate mRNA pools and abundance to rapidly adapt to an ever-changing environment [1,2]. The downstream consequence is a rapid $(<1-2 \mathrm{~h})$ cessation or augmentation of 
protein synthesis, irrespective of the transcription rate that may remain unchanged. As transcription may take hours or even days to substantively change, the modulation of mRNA stability, especially in mammalian cells, is one of the most powerful and rapid means to alter protein expression and cellular homeostasis.

In steady state mammalian cells, mRNAs show a wide variety of decay rates. Protein with critical cellular functions such as cytokines, oncogenes, kinases, phosphatases and cell-surface receptors are often, but not exclusively coded by short-lived mRNAs that are unstable in resting cells [1,2]. Along with protein turnover, rapid mRNA decay prevents protein expression and its biological consequences. Not surprisingly, this process is often deranged in tumor cells and likely facilitates their growth. The determinants of mRNA decay (along with mRNA localization) are typically embedded into the 3'-UTR, although 5'-UTR elements have also been described. The best characterized of these are the so-called adenosine-uridine (AU)-rich elements often found in 3'-UTR of early response genes (cytokines, lymphokines and proto-oncogenes). Bioinformatics analysis have suggested that, in humans, AREs occur in up to $5 \% \sim 8 \%$ of all transcripts [3,4] although only $10 \% \sim 15 \%$ of all ARE mRNAs have half-lives below $2 \mathrm{~h}$ [5]. These data suggest that other features may mitigate the destabilizing function of AREs, including their location relative to the stop codon or poly-A tail, the number of reiterations and the spacing between AREs as well as the adjacent, non-ARE sequences. Such sequence variation may alter secondary or tertiary mRNA structure, partially or fully accounting for the observed phenotypes.

Trans-acting factors (e.g., RNA-binding proteins and microRNAs), that bind directly or indirectly to the AREs [6] are essential components for regulated decay. Such binding proteins (ARE-BPs or AUBPs) participate broadly in ARE mRNA metabolism including their nuclear splicing, defect surveillance and cytoplasmic transport, as well as their cytoplasmic stability, translation and subcellular localization. Proteins can be loaded onto pre- or mature ARE mRNAs in both the nucleus and the cytoplasm. The first cytoplasmic AUBP was identified using RNA mobility shift assays with leukemia cell lysates and in vitro transcribed, radiolabeled ARE RNA fragments derived from GM-CSF mRNA [7]. AUF1 was the first AUBP to be cloned and approximately 20 additional AUBPs [8-10] have since been identified suggesting a class of proteins with a broad range of function and possible redundancy. It is worth noting that AUBPs recognize their targets through a combination of primary sequence and secondary, tertiary or potentially quaternary conformation. The latter sets AUBPs (and other RNA-binding proteins) apart from DNA binding proteins. Given this complexity, it is not surprising that relatively little is known about how AUBPs identify and interact with their targets and what signaling cascades affect their function.

AUBPs bind to AREs via a variety of domains including the so-called RNA-recognition motif (RRM), $\mathrm{CCCH}$ tandem zinc finger, and the K-homology domain ( $\mathrm{KH}$ ) [9]. A single protein may contain multiple motifs implying a capacity for simultaneous interactions with multiple targets or multiple sites within a single target. Perhaps, not surprisingly, AUBPs can accelerate (e.g., AUF1, TTP, and KSRP), or attenuate (e.g., HuR) ARE mRNA decay. Multi-isoform AUBPs such as AUF1 have been shown to both stabilize and destabilize target mRNAs [9], consistent with unique isoform functionality.

The breadth of AUBP-mediated regulation is substantial. For example, a genome-wide analysis identified $\sim 250$ mRNAs that were stabilized in $\mathrm{TTP}^{-/-}$MEFs [11]. These results demonstrate that an individual AUBP can control the decay of many ARE mRNAs simultaneously and imply that despite their redundancy, that specific AUBPs cannot be complemented by the function of other AUBPs [12]. While 250 mRNAs is substantial, it represents far less than $5 \%$ of the predicted number of ARE 
mRNAs in a mammalian cell. Thus, these data also suggest there is likely a subset of ARE targets that are selective ligands of individual AUBPs. This is consistent with observations showing that some AUBPs have modest effects on mRNA decay but instead modulate the translation of mRNA targets. For example, TIA-1 and TIAR that bind the ARE in TNF- $\alpha$ mRNA inhibit translation without affecting mRNA decay kinetics. Mechanistically, these AUBPs relocalize target mRNAs from polysomes to untranslatable, mRNP stress granules [13].

The expression of different AUBPs varies depending on cell/tissue types and external stimuli. However, it is clear that multiple AUBPs coexist in cells and that numerous target mRNAs can interact with and presumably be regulated by multiple AUBPs. Thus, a critical question remains as to what determines the recognition between an AUBP and specific target ARE mRNA. As the interaction appears to be extremely plastic and dynamic, signal transduction events that trigger AUBP post-translational modification(s) seem likely to alter the affinity or localization (among other options) of preexisting AUBPs [14,15]. Indeed, AUBPs can be methylated [16], phosphorylated [17], glycosylated [18], and ubiquitinated [19]. Of these, protein-kinase-triggered phosphorylation has been implicated in directing the binding of AUBPs to protein cofactors (e.g., chaperones), mRNA targets and the ubiquitin-proteasome system [14,15,17].

Pin1, a cis-trans prolyl isomerase (PPIase), was cloned from a human cDNA library and found to be essential for cell-cycle progression [20]. Pin1 is highly conserved from yeast to humans and related to the cis-trans isomerases of the cyclophilin and FKBP families. While the latter proteins can isomerize $\mathrm{X}$-Pro peptide bonds (where $\mathrm{X}$ is any amino acid), Pin1 is the only known mammalian isomerase with rigid specificity for Ser-Pro or Thr-Pro peptide bonds. Isomerization is bidirectional with cis to trans or trans to cis conversions but occurs approximately 1000 fold faster when the N-terminal Ser or Thr has been phosphorylated [21-23]. Structurally, Pin1 is bipartite with a 40 amino acid N-terminal, WW domain and a C-terminal isomerase domain [24,25]. The WW domain binds to pSer/pThr-Pro motifs while the catalytic domain is responsible for substrate isomerization. If Ser or Thr is dephosphorylated post-isomerization, the large difference in activity towards unphosphorylated substrates prevents further isomerization and essentially locks the new conformation in place. As trans pSer/pThr-Pro bonds often show enhanced phosphatase accessibility, this is likely a common event.

Pin1 mediated prolyl cis-trans isomerization has profound effects on target protein folding, altering subsequent protein-protein and protein-nucleic acid interactions, protein stability and subcellular localization thereby altering a variety of cellular processes including cell cycle progression, apoptosis, innate and acquired immunity, and gene regulation [21,22,26]. Recent studies have shown that Pin1 regulates cytokine gene expression and immune responses in several disorders (asthma, organ rejection, anti-viral immunity) [22].

In this review, we will discuss the post-translational modification of AUBPs by phosphorylation and potential role of Pin1 isomerization in the regulation of AUBPs conformational remodeling, AUBPs-RNA interaction and ARE mRNA turnover in mammals. Finally, we will address several physiological cytokines and immune disorders associated with the function of Pin1. 
Table 1. AUBP phosphorylation, potential Pin1 binding sites and target mRNAs.

\begin{tabular}{|c|c|c|c|c|c|}
\hline AUBP & Phosphorylation site * & Kinase & $\begin{array}{c}\text { Interaction } \\
\text { w/Pin1 }\end{array}$ & mRNA stability affected by AUBP & $\begin{array}{l}\text { mRNA stability/expression } \\
\text { affected by Pin1 }\end{array}$ \\
\hline AUF1 & Ser83, Ser87, Thr91 & $\begin{array}{l}\text { CK1, GSK3 } \beta, \text { PKA } \\
{[27-29]}\end{array}$ & Yes $[30,31]$ & $\begin{array}{l}\text { c-myc, c-fos, Cyclin D1, GM-CSF, iNOS, IL-1 } \beta, \text { IL-2, IL-3, } \\
\text { IL-6, IL-10, p21, PTH, TNF- } \alpha \text { [32-35] }\end{array}$ & $\begin{array}{l}\text { Cyclin D1, GM-CSF, IL-1 } \beta, \text { IL-2, } \\
\text { IL-6, PTH, TNF- } \alpha[30,36-41]\end{array}$ \\
\hline BRF1 & Ser54, Ser92, Ser203 & AKT, ERK2 [42-44] & $\mathrm{N} / \mathrm{D} * *$ & GM-CSF, IL-3, TNF- $\alpha[8]$ & GM-CSF, TNF- $\alpha[30,38,40]$ \\
\hline DAZAP1 & Thr269, Thr315 & ERK2 $[45,46]$ & $\mathrm{N} / \mathrm{D}$ & Regulates RNA splicing and translation [45-47] & \\
\hline hnRNP C & $\mathrm{N} / \mathrm{D}$ & $\mathrm{N} / \mathrm{D}$ & $\begin{array}{c}\text { No } \\
{[30,31,36]}\end{array}$ & APP, GM-CSF, TGF- $\beta$, Urokinase receptor $[30,36,48-50]$ & GM-CSF, TGF- $\beta[30,36,38]$ \\
\hline $\mathrm{HuR}$ & $\begin{array}{l}\text { Ser88, Ser100, Thr118, } \\
\text { Ser158, Tyr200, Ser202, } \\
\text { Ser221, Ser242, Ser318 }\end{array}$ & $\begin{array}{l}\text { AMPK, MAPKs, CDK1, } \\
\text { CHK2, JAK3, PKCs } \\
{[51-63]}\end{array}$ & $\begin{array}{c}\text { Yes } \\
{[30,31,36]}\end{array}$ & $\begin{array}{l}\text { AFT-2, C/EBP- } \beta, \text { Cyclin A/B1/D1, Cox-2, cPLA2 } \alpha \text {, CXCL8, } \\
\text { CXCL1/5, c-fos, D111, DNMT3B, GATA3, GM-CSF, iNOS, } \\
\text { IL-3, IL-8, MyoD, Myogenin, Musashi1, NPM, p21, PEPCK, } \\
\text { RGS4, SIRT1, SMN, Survivin, TNF- } \alpha \text {, VEGF, VHL, XIAP } \\
\text { [8,50,56,64-78] }\end{array}$ & $\begin{array}{l}\text { Cyclin D1, Cox-2, GM-CSF, } \\
\text { iNOS, IL-8, TNF- } \alpha, \text { VEGF } \\
{[30,38,40,79,80]}\end{array}$ \\
\hline KSRP & Ser193, Thr692 & AKT, p38 MAPK $[81,82]$ & Yes [37] & $\begin{array}{l}\beta \text {-catenin, c-fos, c-jun, GAP43, IL-2, iNOS, MyoD, Myogenin, } \\
\text { p21, TNF- } \alpha[8,64,81-83]\end{array}$ & $\begin{array}{l}\text { IL- } 2 \text {, iNOS, } \beta \text {-catenin, TNF- } \alpha \\
{[40,84-87]}\end{array}$ \\
\hline $\mathrm{La}(\mathrm{SSB})$ & Thr301, Ser366, Thr389 & AKT, CK2 [88-91] & $\mathrm{N} / \mathrm{D}$ & Regulates RNA translation $[88,90,91]$ & \\
\hline NF90 & Ser482, Ser647 & AKT, PKC- $\beta$ [92-94] & $\mathrm{N} / \mathrm{D}$ & Cyclin E1, IL-2, MKP-1 [95-97] & IL-2 [84] \\
\hline Nucleolin & Thr641, Thr707 & $\begin{array}{l}\text { CDK1,CDC2,CK2,GSK3 } \beta, \\
\text { PI3K [98-102] }\end{array}$ & No $[30]$ & $\begin{array}{l}\text { Bcl-xL, } \beta \text {-globin, CD154, GM-CSF, Gadd45a, Gastrin, HIF1 } \alpha \text {, } \\
\text { IL-2, p53 [18,102-110] }\end{array}$ & IL-2, GM-CSF $[30,38,84]$ \\
\hline SLBP & Ser60, Thr62, Thr171 & $\mathrm{N} / \mathrm{D}[111-113]$ & Yes [26,31] & Histone [26] & Histone [26] \\
\hline TIA-1/R & $\mathrm{N} / \mathrm{D}$ & FASTK [114-116] & $\begin{array}{c}\text { No } \\
{[30,31,36]}\end{array}$ & Regulates RNA translation [13] & \\
\hline TTP & $\begin{array}{l}\text { Ser52, Ser66, Ser88, Thr92, } \\
\text { Ser93, Ser169, Ser178, } \\
\text { Ser186, Ser197, Ser218, } \\
\text { Ser220, Ser228, Ser245, } \\
\text { Thr250, Ser276, Ser296 }\end{array}$ & $\begin{array}{l}\text { AKT, GSK3 } \beta, \text { MK2, } \\
\text { MAPKs, PKA, PKC } \\
{[117-125]}\end{array}$ & $\mathrm{N} / \mathrm{D}$ & $\begin{array}{l}\text { Bdp1, Claudin-1, Cyclin D1, c-fos, Cox-2, GM-CSF, IL-1 } \alpha \text {, } \\
\text { IL-2, IL-3, IL-6, IL-8, IL-10, IL-23, ler3, IFN- } \gamma \text {, iNOS, LIF, } \\
\text { Mllt1 1, c-myc, Pim3, PLK3, PHLDA1, PAI-2, Pitx2, Rusc2, } \\
\text { TNF- } \alpha \text {, VEGF }[32,126,127]\end{array}$ & $\begin{array}{l}\text { Cox-2, GM-CSF, IL-2, IL-8, } \\
\text { IFN- } \gamma \text {, iNOS, TNF- } \alpha, \text { VEGF } \\
{[30,38,40,79,84,85]}\end{array}$ \\
\hline YB1 & Ser316 & $\begin{array}{l}\text { AKT, ERK2, GSK3 } \beta, J N K \\
{[103,128-130]}\end{array}$ & No $[30]$ & IL-2 $[32,103,128]$ & IL-2 [84] \\
\hline
\end{tabular}

\footnotetext{
* Phosphorylation residues highlighted in bold are the potential Pin1 binding sites (Pro-Ser/Thr). **N/D: not determined.
} 


\section{Post-translational Regulation of AUBPs by Phosphorylation}

Kinases involved in AUBP phosphorylation and ARE mRNA stability include the proline directed kinases (MAPKs, CDKs and FA/GSK3) and others (AMPK, PKCs, PKA, CKs, and PI3K/AKT) (Table 1). The MAPKs and PI3K/AKT are the most studied signaling pathways regulating ARE-mediated post-transcriptional events [131] (Table 1). How the triggering of these signaling pathways results in modulation of ARE mRNA decay remains poorly understood. These kinases are associated with phosphorylation of a range of AUBPs at serine or threonine residues, including TTP (Ser52 and Ser178) [117], DAZAP1 (Thr269 and Thr315) [45], La (Ser366) [88], HuR (Ser221 and Ser318) [51], KSRP (S193 and T692) [132], AUF1 (Ser83 and Ser87) [133], BRF1 (S54, S92, S203 and T270) [42] and NF90 (Ser647) [92] (see Table 1 for details). Despite this growing list of kinase sites, the functional significance of these events remains murky. Nonetheless, as blockade of signal transduction or specific kinases clearly alters ARE mRNA decay, these phosphorylation events must be critically important and likely relevant to many diseases such as pathologic inflammation and cancer [131]. Here, we will selectively focus on the phosphorylation of a subset of AUBPs that has been most extensively studied and are potential Pin1 targets.

TTP is a destabilizing AUBP that can be phosphorylated in murine cells by MK2 (substrate of p38 MAPK) at two serine residues [117]. Phosphorylation is required for TTP to bind the 14-3-3 adaptor protein, attenuating its ARE mRNA destabilizing activity [118,134]. Serine phosphorylation is also associated with the nuclear export of TTP in response to mitogens or serum $[119,135]$. TTP deficient mice stabilize TNF- $\alpha$ mRNA leading to massive overproduction of TNF- $\alpha$ [119]. Not surprisingly, the mice suffer from severe spontaneous inflammation and autoimmunity manifested as arthritis and dermatitis. Consistent with a regulatory role, $\mathrm{MK}^{-/-}$knockout mice show low TNF- $\alpha$ levels while double $\mathrm{MK}^{-/-}: \mathrm{TTP}^{-/-}$mice express high levels of TNF, reminiscent of $\mathrm{TTP}^{-/-}$mice [120]. These data suggest that TTP phosphorylation (Ser52 and Ser178) by MK2 and subsequent interaction with adaptor molecules reduces ARE mRNA affinity and/or impairs the recruitment of the mRNA decay machinery (e.g., exosome) to TNF transcripts. As PKC- $\delta$ and IKK $\beta$-induced phosphorylation of TTP can also interfere with the mRNA binding and destabilizing actions of TTP [136], it is likely that there are redundant kinase signals that regulate TTP. MK2 can be counterbalanced by the protein phosphatase PP2A, which directly competes with 14-3-3 protein for binding to TTP [137]. Dephosphorylation of TTP by PP2A activated ARE mRNA decay. This function of PP2A may be of particular importance during immune response when cytokine levels change and the coding mRNAs are rapidly metabolized. Well-established target mRNAs for TTP binding include TNF- $\alpha$, GM-CSF, IL-2, IL-3, c-fos, COX-2 and VEGF. Transcriptome analysis using RNA from TTP wild-type and knockout cells identified additional target mRNAs [11,12] (Table 1). In summary, TTP may constitute an attractive AUBP for novel anti-inflammatory therapeutic concepts.

AUF1 (hnRNP D) appears to be unique as an AUBP with both stabilizing and destabilizing activity. It can destabilize (c-myc, c-fos, GM-CSF, IL-3, p21, cyclin D1, and iNOS) or stabilize (c-myc, c-fos, GM-CSF, IL-1 $\beta$, TNF- $\alpha$, PTH) ARE mRNAs (Table 1). Alternative splicing of AUF1 transcripts yields four different protein isoforms p37, p40, p42 and p45. Each exhibits unique biochemical characteristics that mediate distinctive RNA-phenotypes. Thus, the regulatory control by AUF1 isoforms appears to be complex than other AUBPs and is further expanded by the potential for AUF1 proteins to form 
heterodimers [138] and by post-translational modifications of specific isoforms. Indeed, each isoform shows a different affinity for ARE containing mRNAs (p37 > p42 > p45 > p40) and can be expressed differentially in cell-specific fashion $[139,140]$. The opposing effects of AUF1 on mRNA stability may result from the relative levels of each isoform in a given cell type or in response to a specific stimulus. The p37 isoform has been shown to interact with the exosome and to exhibit the greatest destabilizing activity toward ARE-containing mRNAs but similarly detailed analysis of the properties of other isoforms has not been reported. All isoforms can undergo post-translational modifications such as methylation [141], ubiquitination [142] and phosphorylation, all of which affects mRNA binding affinity, intracellular trafficking and protein binding affinity to other associated factors [143].

The first phosphorelationsites in p40 AUF1 were identified on Ser83 and Ser87 in polysome-associated protein [27,28]. These serines are encoded by exon 2, which are absent in p37 and p42 AUF1. In THP-1 monocytic leukemia cells, stimulation with phorbol ester induced dephosphorylation of these residues concomitant with stabilization of several candidate AUF1-binding mRNAs (IL-1 $\beta$ and TNF- $\alpha$ ) $[28,133]$. In contrast, p40 AUF1 phosphorylation at these sites destabilized target mRNAs. Because p37 AUF1 lacks these residues, activation of signaling pathways could selectively activate or inactivate p40. In the absence of p40, p37 function may be unopposed. p40 AUF1 can be phosphorylated in vitro on Ser87 and Ser83 by protein kinase A (PKA) and glycogen synthase kinase 3 beta (GSK3 $\beta$ ), respectively [144] (Table 1). The in vivo action of these kinases on AUF1 has not been confirmed et but Ser83 phosphorylation may require prior Ser87 phosphorylation. Phospho-Base predicted seven additional phosphorylation sites, but to date, only CK1 site at Thr91 has been investigated [29]. The fact that all three sites mapped to exon 2 suggests that p45 AUF1 might also be similarly phosphorylated although this hypothesis has not been confirmed. Furthermore, cellular radiolabeling and two-dimensional Western analyses indicated that other AUF1 isoforms can also be modified on Ser, Thr and Tyr residues [145], Collectively, these observations imply diverse regulation of AUF1 isoforms. In cancer cells, the fusion oncokinase NPM-ALK bound to, and hyperphosphorylated all AUF1 isoforms [145]. Mass spectrometric analysis revealed p45 AUF1 bound to NPM-ALK, and both proteins colocalized within cytoplasmic granules. Under these conditions, c-myc and cyclin ARE mRNAs were stabilized with potential oncogenesis [145].

HuR promotes ARE mRNA stability and translation through high affinity binding to the ARE. Overexpression of HuR substantially increases the half-life of many short-lived mRNAs, including those coding ATF-2, Cox-2, XIAP, c-fos, p21, iNOS, GM-CSF, VEGF, TNF- $\alpha$, IL-3, IL-8, IL-13, COX-2, and cyclins (Table 1). HuR-dependent, mRNA stabilization seems closely linked to its subcellular localization and phospho-status. While HuR is predominantly nuclear, it can translocate to cytoplasm upon cellular activation [52,146,147]. Nuclear export of HuR was stimulated in response to various stimuli via MAPK [148,149], AMPK [150], Cdk1 [151] and PKC family [152]. Under these conditions, HuR was phosphorylated at many sites (Ser88, Ser100, Thr118, Ser158, Ser202, Ser221, and Ser318) $[51,53-55,153,154]$ through the action of PKC- $\alpha$-delta, Cdk1, Chk2 and p38 MAPK. HuR contains no canonical phosphorylation sites for Erk or JNK MAPK, suggesting alterations in HuR translocation and ARE mRNA binding affinity are mediated primarily by PKCs, Cdk1 and Chk2 [144]. One study [56] showed that phosphorylation at Tyr200 by JAK3 attenuated HuR localization to stress granules (SG) and reduced HuR interactions with targets SIRT1 and VHL mRNAs. Under these 
conditions, both mRNAs decayed more quickly. To date, the precise mechanism and overall impact of kinases in HuR-dependent mRNA stabilization remain incompletely understood.

The p38-dependent regulation of KSRP plays an important role in the turnover of myogenic transcripts of p21, myogenin and MyoD [81]. Other mRNAs targeted by KSRP include c-fos, iNOS and TNF- $\alpha$ (Table 1). Phosphorylation of KSRP reduced its binding to ARE-containing transcripts, thus reducing their rapid decay [81]. AKT-mediated phosphorylation at a unique serine residue within the N-terminal, KH domain (KH) of KSRP inactivated the destabilizing activity of KSRP, possibly by enhancing interactions with 14-3-3 and blocking association with the exosome [155]. These regulatory pathways are thus similar to that seen with AUF1 (Figure 1).

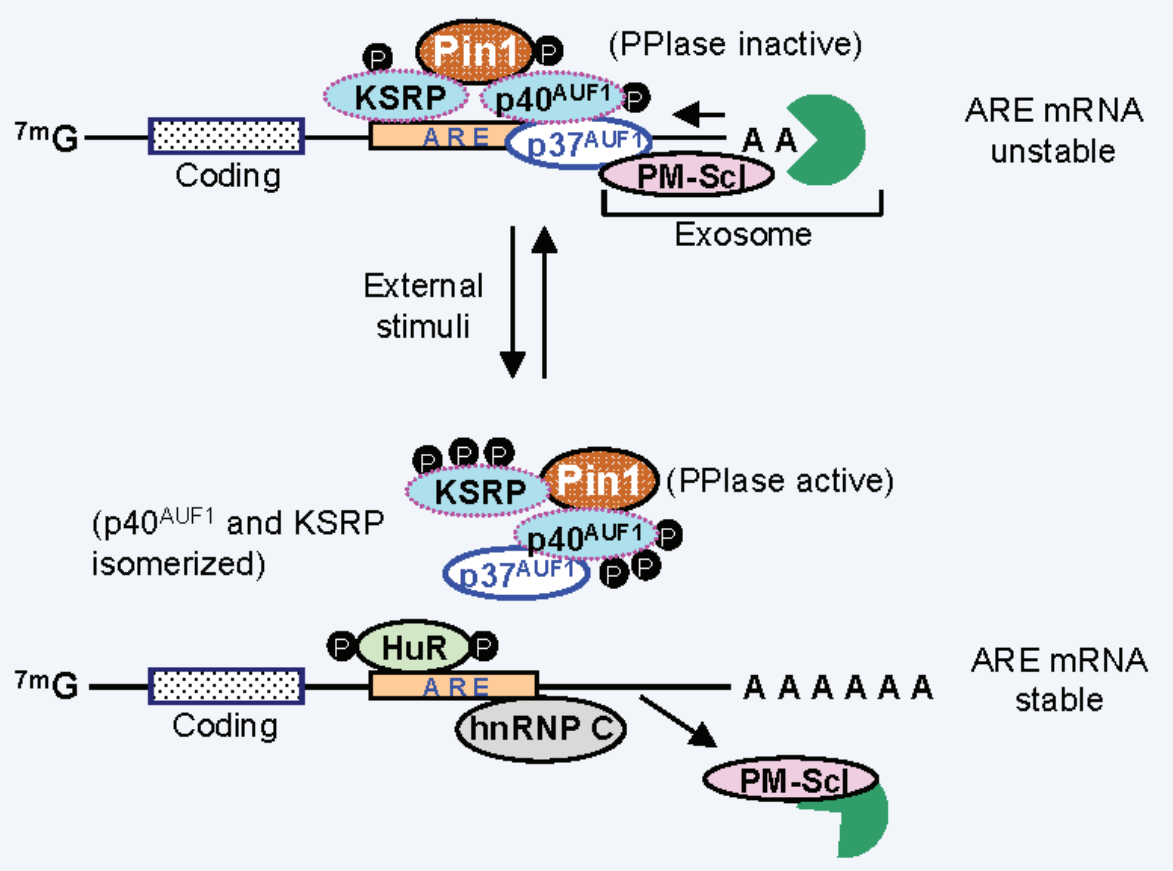

Figure 1. Regulation of ARE mRNA turnover by prolyl cis-trans isomerase Pin1. In response to external stimuli, AUBPs rapidly undergo post-tranlational modification by phosphorylation and dephosphorylation. Pin1 binds phosphorylated AUBPs (p40 AUF1 and KSRP) at pSer/pThr-Pro motifs and, upon activation by dephosphorylation, isomerizes the AUBPs. This cause reconstitution and remodeling of AUBPs-mRNA-exosome complex resulting in changes in the interaction between AUBPs and mRNA as well as mRNA and the exosome $[30,36-38,64,81,82,155]$.

\section{Pin1 Is Associated with AUBPs and Regulates Cytokine mRNA Stability}

As discussed above, the regulation of ARE mRNA decay depends on the regulated phosphorylation of a variety of AUBPs. Under normal conditions, post-transcriptional mechanisms rapidly and substantially alter the levels of ARE mRNAs. As most pro-inflammatory cytokines are coded by ARE-containing mRNAs, this process is essential to ramp up cytokine expression after infection or injury as well as 
quench expression for a return to normal homeostasis. While intracellular phosphorylation clearly altered the assembly and ARE binding affinity of p40 AUF1 [27,28,143], we were unable to reproduce these findings with in vitro synthesized GM-CSF mRNA and mutant AUF1 isoforms [156]. These results suggested that additional steps/regulators were involved in modulating AUF1 function after phosphorylation. Co-immunoprecipitation and gene knockout studies have shown that Pin1 interacts with multiple AUBPs (AUF1, HuR, and KSRP,) and RNA-binding protein (SLBP) in tumor and immune cells $[30,31,36]$ (Table 1) although the interaction may depend on cell type and environmental stimuli. All these molecules have 1-3 canonical Pin1 binding sites (Ser/Thr-Pro) (highlighted in bold in Table 1) that are phosphorylated by various kinases. DAZAP1 and TTP have several phosphorylation Pin1 sites and their interaction with Pin1 has not been determined. Functionally, Pin1 modulated the expression of a number of cytokines/growth factors (GM-CSF, TGF- $\beta$, IL-4, IFN- $\gamma$, IL-1 $\beta$, CXCL-10, PAI-1, FGF-1, TSLP, CTGF, IL-2, and IL-5) in various cell types (leukocytes, T cells and mesenchymal cells) and tissues [30,36,84,157,158].

The same signaling cascades that mediate AUBP phosphorylation appear to act on Pin1 to modulate its activity [30,36]. While Pin1 levels and nuclear localization show gradual changes during the cell cycle, Pin1 isomerase activity can be rapidly (seconds to minutes) modulated by cytokine-driven signaling $[30,36,84,157,158]$, presumably coincident with the phosphorylation of target sites. Activity can be measured in cell lysates using a pentapeptide substrate, permitting analysis of Pin1 regulation. Importantly, primary eosinophils and $\mathrm{T}$ cells obtained from patients with active asthma showed significantly elevated Pin1 isomerase activity that mirrored data from in vitro activated cells obtained from healthy donors [84,156]. Therefore, the modulation of Pin 1 activity occurs in human disease and can be modeled through in vitro agonists.

In the context of AUBPs, Pin1 constitutively interacted with the AUF1 complex in eosinophil cytoplasm [30] (Figure 1). Cell activation either in vivo or in vitro, triggered Pin1 activation, leading to attenuation of the GM-CSF mRNA binding capacity of all four AUF1 isoforms. This occurred despite the fact that only p40 and p45 contain Pin1 isomerization sites (Ser83-Pro84 and Ser87-Pro88). The resulting phenotype was enhanced GM-CSF mRNA stability and cytokine release. As GM-CSF blocks the default apoptosis of eosinophils, the excess release of prosurvival cytokine contributed to the accumulation of pathologic cells in the airways of active asthmatics. Conversely, Pin1 blockade prevented GM-CSF mRNA stabilization or cytokine secretion, and attenuated allergic inflammation and airway fibrosis in the rodent models of asthma [36]. Pin1 has since been implicated in the regulation of signaling mediated by parathyroid hormone and estrogen receptor as well [37,159]. In a rat model of secondary hyperparathyroidism, Pin1 interacted with phospho-KSRP, with isomerization contributing to its dephosphorylation. This increased the interaction between KSRP and PTH mRNA, resulting in reduced PTH mRNA stability and protein. Consistent with these results, the thyroid of Pin1 null mice displayed increased PTH mRNA levels and elevated serum PTH, indicating a possible role for Pin1 in the pathogenesis of hyperparathyroidism and related diseases. Moreover, in unstimulated tumor cells, the mRNA decay-promoting factor KSRP was required for the rapid degradation of $\beta$-catenin transcripts [82] whereas p38 MAPK-mediated phosphorylation of KSRP at a Pin1 site (pThr692-Pro693) impaired KSRP-RNA interactions and increased target mRNA abundance [81], suggesting that KSRP phosphorylation is also crucial for its mRNA binding capabilities (Table 1 and Figure 1). As AUF1, 
HuR, KSRP and TTP control the decay of many ARE containing mRNAs, Pin1 likely plays a broad role in the expression of additional cytokines, oncogenes and hormones in diverse cells and organs.

\section{Effect of Pin1 Prolyl Directed, Cis-Trans Isomerization Activity on mRNA-AUBP Complex Remodeling}

Post-translational modifications have impact on protein conformation and thus can alter the ability of AUBPs to bind ARE-containing transcripts. Depending on which AUBP occupies an ARE, the decay rate is increased or decreased. In vitro FRET experiments revealed that non-phosphorylated p40 AUF1 promotes formation of a condensed, less flexible structure within the TNF- $\alpha$ ARE [133]. While dually phosphorylated (Ser83 and Ser87) p40 AUF1 had a slightly lower binding affinity (two-fold) for the same ARE, it maintained the RNA in a less condensed and elongated form. As the phosphorylation of $\mathrm{p} 40$ at Ser83 and Ser87 was associated with stabilization of ARE transcripts, these data suggest that either loss of transcript contact as well as remodeling of protein interactions may underlie the changes in decay. We showed that suppression of phosphorylated AUF1 function during eosinophil or $\mathrm{T}$ cell activation requires isomerization by Pin1 [30,38]. In resting cells, catalytically inactive, phosphorylated Pin 1 can bind to but not alter the ability of AUF1 to interact with and promote the degradation of GM-CSF mRNA. Leukocyte activation induced Pin1's PPIase activity after PP2A mediated dephosphorylation [36], leading to a conformational transition in AUF1 that reduced its RNA-binding affinity. The mechanism for attenuated RNA binding may also include an inability to recruit critical cofactors including PM-Scl-75 [36] (Figure 1). The latter is particularly relevant as many protein cofactors have been identified as AUBP partners and include translation initiation factors, ubiquitinase, heat shock proteins, and nucleases [13]. Pin1-mediated ARE RNA metabolism is further supported by the observation that Pin 1 is also associated with ARE-independent mRNA binding proteins such as SLBP and regulates PP2A-mediated mRNA decay and protein translation [26]. Pinl regulated SLBP ubiquitination-modulated histone mRNA stability in a cell cycle-dependent manner. Phosphorylation of SLBP at Thr62 and Thr171 was crucial for the interaction with Pin1, which allowed dissociation of histone mRNA from SLBP. The Pin1-SLBP interaction was bipartite involving both the WW and PPIase domains [26,160], although the WW domain is known to have a 10-fold higher binding affinity for substrates than the PPIase domain [161,162]. In the majority of cases, both binding and catalytic activity of Pin1 are required for changes in the target protein molecular functions but in few circumstances, binding alone was reported to be sufficient [163-165]. Therefore, it is possible that in some situations Pin1 mediated prolyl cis-trans isomerization is not required for the effect of AUBPs on target mRNA turnover. Moreover, a role for phospho-HuR in modulating miRNA access to mRNA has been proposed by several independent studies, and may involve similar mechanisms as discussed above [166-168]. Collectively, modification-dependent AUBP regulation is similar to the recruitment of co-regulator complexes to gene promoters, and requires the simultaneous recognition of phosphoproteins and adjacent DNA sequences $[169,170]$. As Pin1 can bind transcription factors associated with many pro-inflammatory genes [22], Pin1 mediated prolyl cis-trans isomerization and phosphorylation-dependent changes in the architecture of AUBPs and local RNA/DNA structure provides a diverse population of molecular determinants to direct downstream macromolecular events. 


\section{Pin 1 and Immune Disorders}

ARE-mediated post-transcriptional regulation is particularly important for a rapid cellular response. This is observed during defense against pathogens, cardiovascular toning, organ rejection, and allergic reactions $[22,140,171,172]$. Primary dysregulation of Pin1 expression or its isomerase activity may be relevant for diseases where aberrant cell-cycle progression and cytokine production are contributing factors. This is likely the case in cancer where Pin1 is often overexpressed. Indeed, Pin1 overexpression has been linked to poor prognosis for breast cancer [22,163]. These data suggest that Pin1 could be an attractive therapeutic target. Given Pin1's relationship to FKBP and cyclophilin families, we asked if Pin1 blockade could reduce the rejection of MHC mismatched lung transplants in rats. Splenic T cells from rats fed juglone, a moderately specific Pin1 inhibitor, showed significantly less IFN- $\gamma$ and IL-2 mRNA and protein compared to untreated controls [84]. Pin1 KO T cells showed similar phenotypes to juglone treated, WT cells. IL-2 mRNA is stabilized by activated immune cells as a prelude to cytokine expression during allograft rejection. In vivo treatment with juglone not only suppressed cytokine production but also preserved transplanted organ architecture and function [84,158]. This observation suggests that Pin1 plays a role in mediating Type 1 immunity and organ rejection. Subsequent studies [36] also demonstrated an essential role for Pin1 in allergic disease. In animal models of asthma, systemic delivery of Pin1 inhibitors prevented airway inflammation by blocking the expression of eosinophil survival cytokines (GM-CSF and IL-5). T cells and eosinophils from juglone treated animals or Pin1 KO mice showed reduced cytokine mRNA and protein expression consistent with the post-transcriptional regulatory processes discussed above. In the context of primary viral infection, there is also growing evidence that Pin1 may be co-opted by viral proteins. For example, during virus infection, Pin1 isomerized viral integrase as well as cellular IRF3 required for efficient virus replication and IRF-3-dependent production of IFN- $\beta$, respectively $[173,174]$. As many immune disorders involve dysregulated IFNs (diabetes, multiple sclerosis and lupus), and GM-CSF production (macrophage mediated tissue damage, gastritis, myeloproliferative syndromes and eosinophilia) [158,175-177], Pin1 likely plays an important role in these pathologies through multiple mechanism controlling the production of immune mediators.

\section{Conclusions}

The regulation of mRNA stability through the ARE allows a fine-tuning of responses to extra- and intra-cellular signals. The process requires the regulated association of one or more AUBPs with target mRNAs in a sequential manner. Proper regulation of AUBPs is thus essential for normal cellular, tissue, and organ homeostasis. While kinase-mediated AUBP phosphorylation is critical, downstream events including Pin1 mediated binding and isomerization are also important. As seen in a variety of pathologies including cancer, allergy and infection, Pin1 dysregulation can have profound consequences. Critical, unanswered questions include the identification of additional Pin1 AUBP targets, characterization of how the cis-trans conversion alters AUBP binding to targets or cofactors and how drugs can be developed that can affect Pin1 or its interaction with protein ligands. 


\section{Acknowledgments}

This study was supported by P01 HL088594 to James S. Malter.

\section{Conflicts of interest}

The authors declare that they have no competing interest.

\section{References}

1. Schoenberg, D.R.; Maquat, L.E. Regulation of cytoplasmic mRNA decay. Nat. Rev. Genet. 2012, 13, 246-259.

2. Pérez-Ortín, J.E.; Alepuz, P.; Chávez, S.; Choder, M. Eukaryotic mRNA decay: Methodologies, pathways, and links to other stages of gene expression. J. Mol. Biol. 2013, 425, 3750-3775.

3. Bakheet, T.; Williams, B.R.; Khabar, K.S. ARED 2.0: An update of AU-rich element mRNA database. Nucleic Acids Res. 2003, 31, 421-423.

4. Halees, A.S.; El-Badrawi, R.; Khabar, K.S. ARED Organism: expansion of ARED reveals AU-rich element cluster variations between human and mouse. Nucleic Acids Res. 2008, 36, D137-D140.

5. Yang, E.; van Nimwegen, E.; Zavolan, M.; Rajewsky, N.; Schroeder, M.; Magnasco, M.; Darnell, J.E., Jr. Decay rates of human mRNAs: Correlation with functional characteristics and sequence attributes. Genome Res. 2003, 13, 1863-1872.

6. Gingerich, T.J.; Feige, J.J.; LaMarre, J. AU-rich elements and the control of gene expression through regulated mRNA stability. Anim. Health Res. Rev. 2004, 5, 49-63.

7. Malter, J.S. Identification of an AUUUA-specific messenger RNA binding protein. Science 1989, 246, 664-666.

8. Barreau, C.; Paillard, L.; Osborne, H.B. AU-rich elements and associated factors: Are there unifying principles? Nucleic Acids Res. 2006, 33, 7138-7150.

9. Stoecklin, G.; Anderson, P. Posttranscriptional mechanisms regulating the inflammatory response. Adv. Immunol. 2006, 89, 1-37.

10. Shaw, G.; Kamen, R. A conserved AU sequence from the 3' untranslated region of GM-CSF mRNA mediates selective mRNA degradation. Cell 1986, 46, 659-667.

11. Stoecklin, G.; Tenenbaum, S.A.; Mayo, T.; Chittur, S.V.; George, A.D.; Baroni, T.E.; Blackshear, P.J.; Anderson, P. Genome-wide analysis identifies interleukin-10 mRNA as target of tristetraprolin. J. Biol. Chem. 2008, 283, 11689-11699.

12. Lai, W.S.; Parker, J.S.; Grissom, S.F.; Stumpo, D.J.; Blackshear, P.J. Novel mRNA argets for tristetraprolin (TTP) identified by global analysis of stabilized transcripts in TTP-deficient fibroblasts. Mol. Cell Biol. 2006, 26, 9196-9208.

13. Zhang, T.; Kruys, V.; Huez, G.; Gueydan, C. AU-rich element-mediated translational control: Complexity and multiple activities of trans-activating factors. Biochem. Soc. Trans. 2002, 30, 952-958.

14. Thapar, R.; Denmon, A.P. Signaling pathways that control mRNA turnover. Cell Signal 2013, 25, 1699-1710.

15. Chen, C.Y.; Shyu, A.B. Emerging mechanisms of mRNP remodeling regulation. Wiley Interdiscip. Rev. RNA 2014, 5, 713-722. 
16. Liu, Q.; Dreyfuss, G. In vivo and in vitro arginine methylation of RNA-binding proteins. Mol. Cell Biol. 1995, 15, 2800-2808.

17. Eberhardt, W.; Doller, A.; Pfeilschifter, J. Regulation of the mRNA-binding protein HuR by posttranslational modification: Spotlight on phosphorylation. Curr. Protein Pept. Sci. 2012, 13, 380-390.

18. Zhang, D.; Liang, Y.; Xie, Q.; Gao, G.; Wei, J.; Huang, H.; Li, J.; Gao, J.; Huang, C. A novel post-translational modification of nucleolin, SUMOylation at K294, mediates Arsenite-induced cell death by regulating GADD45 $\alpha$ mRNA stability. J. Biol. Chem. 2015, doi:10.1074/jbc.M114.598219.

19. Laroia, G.; Sarkar, B.; Schneider, R.J. Ubiquitin-dependent mechanism regulates rapid turnover of AU-rich cytokine mRNAs. Proc. Natl. Acad. Sci. USA 2002, 99, 1842-1846.

20. Lu, K.P.; Hanes, S.D.; Hunter, T. A human peptidyl-prolyl isomerase essential for regulation of mitosis. Nature 1996, 380, 544-547.

21. Pastorino, L.; Sun, A.; Lu, P.J.; Zhou, X.Z.; Balastik, M.; Finn, G.; Wulf, G.; Lim, J.; Li, S.H.; $\mathrm{Li}, \mathrm{X}$; et al. The prolyl isomerase Pin1 regulates amyloid precursor protein processing and amyloid-beta production. Nature 2006, 440, 528-534.

22. Esnault, S.; Shen, Z.J.; Malter, J.S. Pinning down signaling in the immune system: The role of the peptidyl-prolyl isomerase Pin1 in immune cell function. Crit. Rev. Immunol. 2008, 28, 45-60.

23. Ranganathan, R.; Lu, K.P.; Hunter, T.; Noel, J.P. Structural and functional analysis of the mitotic rotamase Pin1 suggests substrate recognition is phosphorylation dependent. Cell 1997, 89, 875-886.

24. Verdecia, M.A.; Bowman, M.E.; Lu, K.P.; Hunter, T.; Noel, J.P. Structural basis for phosphoserine-proline recognition by group IV WW domains. Nat. Struct. Biol. 2000, 7, 639-643.

25. Zhang, Y.; Daum, S.; Wildemann, D.; Zhou, X.Z.; Verdecia, M.A.; Bowman, M.E.; Lücke, C.; Hunter, T.; Lu, K.P.; Fischer, G.; et al. Structural basis for high-affinity peptide inhibition of human Pin1. ACS Chem. Biol. 2007, 2, 320-328.

26. Krishnan, N.; Lam, T.T.; Fritz, A.; Rempinski, D.; O’Loughlin, K.; Minderman, H.; Berezney, R.; Marzluff, W.F.; Thapar, R. The prolyl isomerase Pin1 targets stem-loop binding protein (SLBP) to dissociate the SLBP-histone mRNA complex linking histone mRNA decay with SLBP ubiquitination. Mol. Cell Biol. 2012, 32, 4306-4322.

27. Zhang, W.; Wagner, B.J.; Ehrenman, K.; Schaefer, A.W.; DeMaria, C.T.; Crater, D.; DeHaven, K.; Long, L.; Brewer, G. Purification, characterization, and cDNA cloning of an AU-rich element RNA-binding protein, AUF1. Mol. Cell Biol. 1993, 13, 7652-7665.

28. Wilson, G.M.; Lu, J.; Sutphen, K.; Sun, Y.; Huynh, Y.; Brewer, G. Regulation of A + U-rich element-directed mRNA turnover involving reversible phosphorylation of AUF1. J. Biol. Chem. 2003, 278, 33029-33038.

29. Kreegipuu, A.; Blom, N.; Brunak, S. PhosphoBase, a database of phosphorylation sites: Release 2.0. Nucleic Acids Res. 1999, 27, 237-239.

30. Shen, Z.J.; Esnault, S.; Malter, J.S. The peptidyl-prolyl isomerase Pin1 regulates the stability of granulocyte-macrophage colony-stimulating factor mRNA in activated eosinophils. Nat. Immunol. 2005, 6, 1280-1287.

31. Krishnan, N.; Titus, M.A.; Thapar, R. The prolyl isomerase pin1 regulates mRNA levels of genes with short half-lives by targeting specific RNA binding proteins. PLOS ONE 2014, 9, e85427. 
32. Stumpo, D.J.; Lai, W.S.; Blackshear, P.J. Inflammation: Cytokines and RNA-based regulation. Wiley Interdiscip. Rev. RNA 2010, 1, 60-80.

33. Paschoud, S.; Dogar, A.M.; Kuntz, C.; Grisoni-Neupert, B.; Richman, L.; Kühn, L.C. Destabilization of interleukin-6 mRNA requires a putative RNA stem-loop structure, an AU-rich element, and the RNA-binding protein AUF1. Mol. Cell Biol. 2006, 26, 8228-8241.

34. Sarkar, S.; Sinsimer, K.S.; Foster, R.L.; Brewer, G.; Pestka, S. AUF1 isoform-specific regulation of anti-inflammatory IL10 expression in monocytes. J. Interferon Cytokine Res. 2008, 28, 679-691.

35. Ishimaru, D.; Zuraw, L.; Ramalingam, S.; Sengupta, T.K.; Bandyopadhyay, S.; Reuben, A.; Fernandes, D.J.; Spicer, E.K. Mechanism of regulation of Bcl-2 mRNA by nucleolin and A + U-rich element-binding factor 1 (AUF1). J. Biol. Chem. 2010, 285, 27182-27191.

36. Shen, Z.J.; Esnault, S.; Rosenthal, L.A.; Szakaly, R.J.; Sorkness, R.L.; Westmark, P.R.; Sandor, M.; Malter, J.S. Pin1 regulates TGF-beta1 production by activated human and murine eosinophils and contributes to allergic lung fibrosis. J. Clin. Invest. 2008, 118, 479-490.

37. Nechama, M.; Uchida, T.; Mor Yosef-Levi, I.; Silver, J.; Naveh-Many, T. The peptidyl-prolyl isomerase Pin1 determines parathyroid hormone mRNA levels and stability in rat models of secondary hyperparathyroidism. J. Clin. Invest. 2009, 119, 3102-3114.

38. Esnault, S.; Shen, Z.J.; Whitesel, E.; Malter, J.S. The peptidyl-prolyl isomerase Pin1 regulates granulocyte-macrophage colony-stimulating factor mRNA stability in T lymphocytes. J. Immunol. 2006, 177, 6999-7006.

39. Akiyama, H.; Misawa, T.; Ono, M.; Uchida, C.; Uchida, T. Prolyl isomerase Pin1 protects mice from endotoxin shock. PLOS ONE 2011, 6, e14656.

40. Liu, T.; Schneider, R.A.; Lee, N.Y.; Hoyt, D.G. Peptidylprolyl cis/trans isomerase, NIMA-interacting 1 (PIN1) regulates pulmonary effects of endotoxin and tumor necrosis factor- $\alpha$ in mice. Biochem. Biophys. Res. Commun. 2014, 452, 468-472.

41. Miyashita, H.; Uchida, T.; Mori, S.; Echigo, S.; Motegi, K. Expression status of Pin1 and cyclins in oral squamous cell carcinoma: Pin1 correlates with Cyclin D1 mRNA expression and clinical significance of cyclins. Oncol. Rep. 2003, 10, 1045-1048.

42. Maitra, S.; Chou, C.F.; Luber, C.A.; Lee, K.Y.; Mann, M.; Chen, C.Y. The AU-rich element mRNA decay-promoting activity of BRF1 is regulated by mitogen-activated protein kinase-activated protein kinase 2. RNA 2008, 14, 950-959.

43. Benjamin, D.; Schmidlin, M.; Min, L.; Gross, B.; Moroni, C. BRF1 protein turnover and mRNA decay activity are regulated by protein kinase B at the same phosphorylation sites. Mol. Cell Biol. 2006, 26, 9497-9507.

44. Schmidlin, M.; Lu, M.; Leuenberger, S.A.; Stoecklin, G.; Mallaun, M.; Gross, B.; Gherzi, R.; Hess, D.; Hemmings, B.A.; Moroni, C. The ARE-dependent mRNA-destabilizing activity of BRF1 is regulated by protein kinase B. EMBO J. 2004, 23, 4760-4769.

45. Morton, S.; Yang, H.T.; Moleleki, N.; Campbell, D.G.; Cohen, P.; Rousseau, S. Phosphorylation of the ARE-binding protein DAZAP1 by ERK2 induces its dissociation from DAZ. Biochem. J. 2006, 399, 265-273.

46. Smith, R.W.; Anderson, R.C.; Smith, J.W.; Brook, M.; Richardson, W.A.; Gray, N.K. DAZAP1, an RNA-binding protein required for development and spermatogenesis, can regulate mRNA translation. RNA 2011, 17, 1282-1295. 
47. Chen, H.Y.; Yu, Y.H.; Yen, P.H. DAZAP1 regulates the splicing of Crem, Crisp2 and Pot1a transcripts. Nucleic Acids Res. 2013, 41, 9858-9869.

48. Rajagopalan, L.E.; Westmark, C.J.; Jarzembowski, J.A.; Malter, J.S. hnRNP C increases amyloid precursor protein (APP) production by stabilizing APP mRNA. Nucleic Acids Res. 1998, 26, 3418-3423.

49. Shetty, S. Regulation of urokinase receptor mRNA stability by hnRNP C in lung epithelial cells. Mol. Cell Biochem. 2005, 272, 107-118.

50. Esnault, S.; Malter, J.S. Hyaluronic acid or TNF-alpha plus fibronectin triggers granulocyte macrophage-colony-stimulating factor mRNA stabilization in eosinophils yet engages differential intracellular pathways and mRNA binding proteins. J. Immunol. 2003, 171, 6780-6787.

51. Doller, A.; Schlepckow, K.; Schwalbe, H.; Pfeilschifter, J.; Eberhardt, W. Tandem phosphorylation of serines 221 and 318 by protein kinase Cdelta coordinates mRNA binding and nucleocytoplasmic shuttling of HuR. Mol. Cell Biol. 2010, 30, 1397-1410.

52. Kim, H.H.; Yang, X.; Kuwano, Y.; Gorospe, M. Modification at HuR(S242) alters HuR localization and proliferative influence. Cell Cycle 2008, 7, 3371-3377.

53. Abdelmohsen, K.; Pullmann R, Jr.; Lal, A.; Kim, H.H.; Galban, S.; Yang, X.; Blethrow, J.D.; Walker, M.; Shubert, J.; Gillespie, D.A.; et al. Phosphorylation of HuR by Chk2 regulates SIRT1 expression. Mol. Cell. 2007, 25, 543-557.

54. Kim, H.H.; Abdelmohsen, K.; Lal, A.; Pullmann, R., Jr.; Yang, X.; Galban, S.; Srikantan, S.; Martindale, J.L.; Blethrow, J.; Shokat, K.M.; et al. Nuclear HuR accumulation through phosphorylation by Cdk1. Genes Dev. 2008, 22, 1804-1815.

55. Doller, A.; Huwiler, A.; Müller, R.; Radeke, H.H.; Pfeilschifter, J.; Eberhardt, W. Protein kinase C alpha-dependent phosphorylation of the mRNA-stabilizing factor HuR: Implications for posttranscriptional regulation of cyclooxygenase-2. Mol. Biol. Cell. 2007, 18, 2137-2148.

56. Yoon, J.H.; Abdelmohsen, K.; Srikantan, S.; Guo, R.; Yang, X.; Martindale, J.L.; Gorospe, M. Tyrosine phosphorylation of HuR by JAK3 triggers dissociation and degradation of HuR target mRNAs. Nucleic Acids Res. 2014, 42, 1196-1208.

57. Akaike, Y.; Masuda, K.; Kuwano, Y.; Nishida, K.; Kajita, K.; Kurokawa, K.; Satake, Y.; Shoda, K.; Imoto, I.; Rokutan, K. HuR regulates alternative splicing of the TRA2 $\beta$ gene in human colon cancer cells under oxidative stress. Mol. Cell Biol. 2014, 34, 2857-2873.

58. Schulz, S.; Doller, A.; Pendini, N.R.; Wilce, J.A.; Pfeilschifter, J.; Eberhardt, W. Domain-specific phosphomimetic mutation allows dissection of different protein kinase C (PKC) isotype-triggered activities of the RNA binding protein HuR. Cell Signal. 2013, 25, 2485-2495.

59. Doller, A.; Schulz, S.; Pfeilschifter, J.; Eberhardt, W. RNA-dependent association with myosin IIA promotes F-actin-guided trafficking of the ELAV-like protein HuR to polysomes. Nucleic Acids Res. 2013, 41, 9152-9167.

60. Filippova, N.; Yang, X.; King, P.; Nabors, L.B. Phosphoregulation of the RNA-binding protein $\mathrm{Hu}$ antigen $\mathrm{R}$ (HuR) by Cdk5 affects centrosome function. J. Biol. Chem. 2012, 287, 32277-32287.

61. Doller, A.; Winkler, C.; Azrilian, I.; Schulz, S.; Hartmann, S.; Pfeilschifter, J.; Eberhardt, W. High-constitutive HuR phosphorylation at Ser 318 by $\mathrm{PKC} \delta$ propagates tumor relevant functions in colon carcinoma cells. Carcinogenesis 2011, 32, 676-685. 
62. Martínez-Chantar, M.L.; Vázquez-Chantada, M.; Garnacho, M.; Latasa, M.U.; Varela-Rey, M.; Dotor, J.; Santamaria, M.; Martínez-Cruz, L.A.; Parada, L.A.; Lu, S.C.; et al. S-adenosylmethionine regulates cytoplasmic HuR via AMP-activated kinase. Gastroenterology 2006, 131, 223-232.

63. Lafarga, V.; Cuadrado, A.; Lopez de Silanes, I.; Bengoechea, R.; Fernandez-Capetillo, O.; Nebreda, A.R. p38 Mitogen-activated protein kinase- and HuR-dependent stabilization of p21 Cip1 mRNA mediates the $\mathrm{G}_{1} / \mathrm{S}$ checkpoint. Mol. Cell Biol. 2009, 29, 4341-4351.

64. Cammas, A.; Sanchez, B.J.; Lian, X.J.; Dormoy-Raclet, V.; van der Giessen, K.; de Silanes, I.L.; Ma, J.; Wilusz, C.; Richardson, J.; Gorospe, M.; et al. Destabilization of nucleophosmin mRNA by the HuR/KSRP complex is required for muscle fibre formation. Nat. Commun. 2014, doi:10.1038/ncomms5190.

65. González-Feliciano, J.A.; Hernández-Pérez, M.; Estrella, L.A.; Colón-López, D.D.; López, A.; Martínez, M.; Maurás-Rivera, K.R.; Lasalde, C.; Martínez, D.; Araujo-Pérez, F.; et al. The role of HuR in the post-transcriptional regulation of interleukin-3 in T cells. PLOS ONE 2014, 9, e92457.

66. Zhang, X.; Zou, T.; Rao, J.N.; Liu, L.; Xiao, L.; Wang, P.Y.; Cui, Y.H.; Gorospe, M.; Wang, J.Y. Stabilization of XIAP mRNA through the RNA binding protein HuR regulated by cellular polyamines. Nucleic Acids Res. 2009, 37, 7623-7637.

67. Hudy, M.H.; Proud, D. Cigarette smoke enhances human rhinovirus-induced CXCL8 production via HuR-mediated mRNA stabilization in human airway epithelial cells. Respir. Res. 2013, doi:10.1186/1465-9921-14-88.

68. Herjan, T.; Yao, P.; Qian, W.; Li, X.; Liu, C.; Bulek, K.; Sun, D.; Yang, W.P.; Zhu, J.; He, A.; et al. HuR is required for IL-17-induced Act1-mediated CXCL1 and CXCL5 mRNA stabilization. J. Immunol. 2013, 191, 640-649.

69. Gummadi, L.; Taylor, L.; Curthoys, N.P. Concurrent binding and modifications of AUF1 and HuR mediate the $\mathrm{pH}$-responsive stabilization of phosphoenolpyruvate carboxykinase mRNA in kidney cells. Am. J. Physiol. Renal Physiol. 2012, 303, F1545-F1554.

70. Vo, D.T.; Abdelmohsen, K.; Martindale, J.L.; Qiao, M.; Tominaga, K.; Burton, T.L.; Gelfond, J.A.; Brenner, A.J.; Patel, V.; Trageser, D.; et al. The oncogenic RNA-binding protein Musashi1 is regulated by HuR via mRNA translation and stability in glioblastoma cells. Mol. Cancer Res. 2012, 10, 143-155.

71. Liao, W.L.; Wang, W.C.; Chang, W.C.; Tseng, J.T. The RNA-binding protein HuR stabilizes cytosolic phospholipase A2 $\alpha$ mRNA under interleukin-1 $\beta$ treatment in non-small cell lung cancer A549 Cells. J. Biol. Chem. 2011, 286, 35499-35508.

72. Donahue, J.M.; Chang, E.T.; Xiao, L.; Wang, P.Y.; Rao, J.N.; Turner, D.J.; Wang, J.Y.; Battafarano, R.J. The RNA-binding protein HuR stabilizes survivin mRNA in human oesophageal epithelial cells. Biochem. J. 2011, 437, 89-96.

73. García-Domínguez, D.J.; Morello, D.; Cisneros, E.; Kontoyiannis, D.L.; Frade, J.M. Stabilization of Dl11 mRNA by Elavl1/HuR in neuroepithelial cells undergoing mitosis. Mol. Biol. Cell. 2011, 22, 1227-1239.

74. Bergalet, J.; Fawal, M.; Lopez, C.; Desjobert, C.; Lamant, L.; Delsol, G.; Morello, D.; Espinos, E. HuR-mediated control of C/EBPbeta mRNA stability and translation in ALK-positive anaplastic large cell lymphomas. Mol. Cancer Res. 2011, 9, 485-496. 
75. Li, F.; Hu, D.Y.; Liu, S.; Mahavadi, S.; Yen, W.; Murthy, K.S.; Khalili, K.; Hu, W. RNA-binding protein HuR regulates RGS4 mRNA stability in rabbit colonic smooth muscle cells. Am. J. Physiol. Cell Physiol. 2010, 299, C1418-C1429.

76. Licata, L.A.; Hostetter, C.L.; Crismale, J.; Sheth, A.; Keen, J.C. The RNA-binding protein HuR regulates GATA3 mRNA stability in human breast cancer cell lines. Breast Cancer Res. Treat. 2010, 122, 55-63.

77. Farooq, F.; Balabanian, S.; Liu, X.; Holcik, M.; MacKenzie, A. p38 Mitogen-activated protein kinase stabilizes SMN mRNA through RNA binding protein HuR. Hum. Mol. Genet. 2009, 18, 4035-4045.

78. López de Silanes, I.; Gorospe, M.; Taniguchi, H.; Abdelmohsen, K.; Srikantan, S.; Alaminos, M.; Berdasco, M.; Urdinguio, R.G.; Fraga, M.F.; Jacinto, F.V.; et al. The RNA-binding protein HuR regulates DNA methylation through stabilization of DNMT3b mRNA. Nucleic Acids Res. 2009, 37, 2658-2671.

79. Atkinson, G.P.; Nozell, S.E.; Harrison, D.K.; Stonecypher, M.S.; Chen, D.; Benveniste, E.N. The prolyl isomerase Pin1 regulates the NF- $\kappa \mathrm{B}$ signaling pathway and interleukin- 8 expression in glioblastoma. Oncogene 2009, 28, 3735-3745.

80. Kim, M.R.; Choi, H.S.; Heo, T.H.; Hwang, S.W.; Kang, K.W. Induction of vascular endothelial growth factor by peptidyl-prolyl isomerase Pin1 in breast cancer cells. Biochem. Biophys. Res. Commun. 2008, 369, 547-553.

81. Briata, P.; Forcales, S.V.; Ponassi, M.; Corte, G.; Chen, C.Y.; Karin, M.; Puri, P.L.; Gherzi, R. p38-dependent phosphorylation of the mRNA decay-promoting factor KSRP controls the stability of select myogenic transcripts. Mol. Cell. 2005, 20, 891-903.

82. Gherzi, R.; Trabucchi, M.; Ponassi, M.; Ruggiero, T.; Corte, G.; Moroni, C.; Chen, C.Y.; Khabar, K.S.; Andersen, J.S.; Briata, P. The RNA-binding protein KSRP promotes decay of beta-catenin mRNA and is inactivated by PI3K-AKT signaling. PLoS Biol. 2006, 5, e5.

83. Bird, C.W.; Gardiner, A.S.; Bolognani, F.; Tanner, D.C.; Chen, C.Y.; Lin, W.J.; Yoo, S.; Twiss, J.L.; Perrone-Bizzozero, N. KSRP modulation of GAP-43 mRNA stability restricts axonal outgrowth in embryonic hippocampal neurons. PLoS ONE 2013, 8, e 79255.

84. Esnault, S.; Braun, R.K.; Shen, Z.J.; Xiang, Z.; Heninger, E.; Love, R.B.; Sandor, M.; Malter, J.S. Pin1 modulates the type 1 immune response. PLOS ONE 2007, 2, e226.

85. Cho, Y.A.; Jue, S.S.; Bae, W.J.; Heo, S.H.; Shin, S.I.; Kwon, I.K.; Lee, S.C.; Kim, E.C. PIN1 inhibition suppresses osteoclast differentiation and inflammatory responses. J. Dent Res. 2015, 94, 371-380.

86. Leung, K.W.; Tsai, C.H.; Hsiao, M.; Tseng, C.J.; Ger, L.P.; Lee, K.H.; Lu, P.J. Pin1 overexpression is associated with poor differentiation and survival in oral squamous cell carcinoma. Oncol. Rep. 2009, 21, 1097-1104.

87. Lin, F.C.; Lee, Y.C.; Goan, Y.G.; Tsai, C.H.; Yao, Y.C.; Cheng, H.C.; Lai, W.W.; Wang, Y.C.; Sheu, B.S.; Lu, P.J. Pin1 positively affects tumorigenesis of esophageal squamous cell carcinoma and correlates with poor survival of patients. J. Biomed. Sci. 2014, doi:10.1186/s12929-014-0075-1.

88. Schwartz, E.I.; Intine, R.V.; Maraia, R.J. CK2 is responsible for phosphorylation of human La protein serine-366 and can modulate rpL37 5'-terminal oligopyrimidine mRNA metabolism. Mol. Cell Biol. 2004, 24, 9580-9591. 
89. Terzoglou, A.G.; Routsias, J.G.; Avrameas, S.; Moutsopoulos, H.M.; Tzioufas, A.G. Preferential recognition of the phosphorylated major linear B-cell epitope of La/SSB 349-368 aa by anti-La/SSB autoantibodies from patients with systemic autoimmune diseases. Clin. Exp. Immunol. 2006, 144, 432-439.

90. Brenet, F.; Socci, N.D.; Sonenberg, N.; Holland, E.C. Akt phosphorylation of La regulates specific mRNA translation in glial progenitors. Oncogene 2009, 28, 128-139.

91. Kuehnert, J.; Sommer, G.; Zierk, A.W.; Fedarovich, A.; Brock, A.; Fedarovich, D.; Heise, T. Novel RNA chaperone domain of RNA-binding protein La is regulated by AKT phosphorylation. Nucleic Acids Res.2015, 43, 581-594.

92. Pei, Y.; Zhu, P.; Dang, Y.; Wu, J.; Yang, X.; Wan, B.; Liu, J.O.; Yi, Q.; Yu, L. Nuclear export of NF90 to stabilize IL-2 mRNA is mediated by AKT-dependent phosphorylation at Ser647 in response to CD28 costimulation. J. Immunol. 2008, 180, 222-229.

93. Smith, N.L.; Miskimins, W.K. Phosphorylation at serine 482 affects stability of NF90 and its functional role in mitosis. Cell Prolif. 2011, 44, 147-155.

94. Zhu, P.; Jiang, W.; Cao, L.; Yu, W.; Pei, Y.; Yang, X.; Wan, B.; Liu, J.O.; Yi, Q.; Yu, L. IL-2 mRNA stabilization upon PMA stimulation is dependent on NF90-Ser647 phosphorylation by protein kinase CbetaI. J. Immunol. 2010, 185, 5140-5149.

95. Jiang, W.; Huang, H.; Ding, L.; Zhu, P.; Saiyin, H.; Ji, G.; Zuo, J.; Han, D.; Pan, Y.; Ding, D.; et al. Regulation of cell cycle of hepatocellular carcinoma by NF90 through modulation of cyclin E1 mRNA stability. Oncogene 2014, doi:10.1038/onc.2014.373.

96. Kuwano, Y.; Kim, H.H.; Abdelmohsen, K.; Pullmann, R., Jr.; Martindale, J.L.; Yang, X.; Gorospe, M. MKP-1 mRNA stabilization and translational control by RNA-binding proteins HuR and NF90. Mol. Cell Biol. 2008, 28, 4562-4575.

97. Shim, J.; Lim, H.; R Yates, J.; Karin, M. Nuclear export of NF90 is required for interleukin-2 mRNA stabilization. Mol. Cell 2002, 10, 1331-1344.

98. Bonnet, H.; Filhol, O.; Truchet, I.; Brethenou, P.; Cochet, C.; Amalric, F.; Bouche, G. Fibroblast growth factor-2 binds to the regulatory beta subunit of CK2 and directly stimulates CK2 activity toward nucleolin. J. Biol. Chem. 1996, 271, 24781-24787.

99. Wang, S.A.; Li, H.Y.; Hsu, T.I.; Chen, S.H.; Wu, C.J.; Chang, W.C.; Hung, J.J. Heat shock protein 90 stabilizes nucleolin to increase mRNA stability in mitosis. J. Biol. Chem. 2011, 286, 43816-43829.

100. Wu, D.M.; Zhang, P.; Liu, R.Y.; Sang, Y.X.; Zhou, C.; Xu, G.C.; Yang, J.L.; Tong, A.P.; Wang, C.T. Phosphorylation and changes in the distribution of nucleolin promote tumor metastasis via the PI3K/Akt pathway in colorectal carcinoma. FEBS Lett. 2014, 588, 1921-1929.

101. Dranovsky, A.; Vincent, I.; Gregori, L.; Schwarzman, A.; Colflesh, D.; Enghild, J.; Strittmatter, W.; Davies, P.; Goldgaber, D. Cdc2 phosphorylation of nucleolin demarcates mitotic stages and Alzheimer's disease pathology. Neurobiol. Aging 2001, 22, 517-528.

102. Cheng, D.D.; Zhao, H.G.; Yang, Y.S.; Hu, T.; Yang, Q.C. GSK3 $\beta$ negatively regulates HIF1 $\alpha$ mRNA stability via nucleolin in the MG63 osteosarcoma cell line. Biochem. Biophys. Res. Commun. 2014, 443, 598-603. 
103. Chen, C.Y.; Gherzi, R.; Andersen, J.S.; Gaietta, G.; Jürchott, K.; Royer, H.D.; Mann, M.; Karin, M. Nucleolin and YB-1 are required for JNK-mediated interleukin-2 mRNA stabilization during T-cell activation. Genes Dev. 2000, 14, 1236-1248.

104. Woo, H.H.; Baker, T.; Laszlo, C.; Chambers, S.K. Nucleolin mediates microRNA-directed CSF-1 mRNA deadenylation but increases translation of CSF-1 mRNA. Mol. Cell. Proteomics 2013, 12, 1661-1677.

105. Wang, W.H.; Childress, M.O.; Geahlen, R.L. Syk interacts with and phosphorylates nucleolin to stabilize Bcl-XL mRNA and promote cell survival. Mol. Cell Biol. 2014, 34, 3788-3799.

106. Lee, P.T.; Liao, P.C.; Chang, W.C.; Tseng, J.T. Epidermal growth factor increases the interaction between nucleolin and heterogeneous nuclear ribonucleoprotein $\mathrm{K} /$ poly $(\mathrm{C})$ binding protein 1 complex to regulate the gastrin mRNA turnover. Mol. Biol. Cell. 2007, 18, 5004-5013.

107. Jiang, Y.; Xu, X.S.; Russell, J.E. A nucleolin-binding 3' untranslated region element stabilizes beta-globin mRNA in vivo. Mol. Cell Biol. 2006, 26, 2419-2429.

108. Zhang, Y.; Bhatia, D.; Xia, H.; Castranova, V.; Shi, X.; Chen, F. Nucleolin links to arsenicinduced stabilization of GADD45 a mRNA. Nucleic Acids Res. 2006, 34, 485-495.

109. Singh, K.; Laughlin, J.; Kosinski, P.A.; Covey, L.R. Nucleolin is a second component of the CD154 mRNA stability complex that regulates mRNA turnover in activated T cells. J. Immunol. 2004, 173, 976-985.

110. Sengupta, T.K.; Bandyopadhyay, S.; Fernandes, D.J.; Spicer, E.K. Identification of nucleolin as an AU-rich element binding protein involved in Bcl-2 mRNA stabilization. J. Biol. Chem. 2004, $279,10855-10863$.

111. Zheng, L.; Dominski, Z.; Yang, X.C.; Elms, P.; Raska, C.S.; Borchers, C.H.; Marzluff, W.F. Phosphorylation of stem-loop binding protein (SLBP) on two threonines triggers degradation of SLBP, the sole cell cycle-regulated factor required for regulation of histone mRNA processing, at the end of S phase. Mol. Cell Biol. 2003, 23, 1590-1601.

112. Bansal, N.; Zhang, M.; Bhaskar, A.; Itotia, P.; Lee, E.; Shlyakhtenko, L.S.; Lam, T.T.; Fritz, A.; Berezney, R.; Lyubchenko, Y.L.; et al. Assembly of the SLIP1-SLBP complex on histone mRNA requires heterodimerization and sequential binding of SLBP followed by SLIP1. Biochemistry 2013, 52, 520-536.

113. Zhang, M.; Lam, T.T.; Tonelli, M.; Marzluff, W.F.; Thapar, R. Interaction of the histone mRNA hairpin with stem-loop binding protein (SLBP) and regulation of the SLBP-RNA complex by phosphorylation and proline isomerization. Biochemistry 2012, 51, 3215-3231.

114. Tian, Q.; Taupin, J.; Elledge, S.; Robertson, M.; Anderson, P. Fas-activated serine/threonine kinase (FAST) phosphorylates TIA-1 during Fas-mediated apoptosis. J. Exp. Med. 1995, 182, 865-874.

115. Izquierdo, J.M.; Valcárcel, J. Fas-activated serine/threonine kinase (FAST K) synergizes with TIA-1/TIAR proteins to regulate Fas alternative splicing. J. Biol. Chem.2007, 282, 1539-1543.

116. Gottschald, O.R.; Malec, V.; Krasteva, G.; Hasan, D.; Kamlah, F.; Herold, S.; Rose, F.; Seeger, W.; Hänze, J. TIAR and TIA-1 mRNA-binding proteins co-aggregate under conditions of rapid oxygen decline and extreme hypoxia and suppress the HIF-1 $\alpha$ pathway. J. Mol. Cell Biol. 2010, 2, 345-356. 
117. Chrestensen, C.A.; Schroeder, M.J.; Shabanowitz, J.; Hunt, D.F.; Pelo, J.W.; Worthington, M.T.; Sturgill, T.W. MAPKAP kinase 2 phosphorylates tristetraprolin on in vivo sites including Ser178, a site required for 14-3-3 binding. J. Biol. Chem. 2004, 279, 10176-10184.

118. Stoecklin, G.; Stubbs, T.; Kedersha, N.; Wax, S.; Rigby, W.F.; Blackwell, T.K.; Anderson, P. MK2-induced tristetraprolin:14-3-3 complexes prevent stress granule association and ARE-mRNA decay. EMBO J. 2004, 23, 1313-1324.

119. Taylor, G.A.; Thompson, M.J.; Lai, W.S.; Blackshear, P.J. Phosphorylation of tristetraprolin, a potential zinc finger transcription factor, by mitogen stimulation in intact cells and by mitogen-activated protein kinase in vitro. J. Biol. Chem. 1995, 270, 13341-13347.

120. Hitti, E.; Iakovleva, T.; Brook, M.; Deppenmeier, S.; Gruber, A.D.; Radzioch, D.; Clark, A.R.; Blackshear, P.J.; Kotlyarov, A.; Gaestel, M. Mitogen-activated protein kinase-activated protein kinase 2 regulates tumor necrosis factor mRNA stability and translation mainly by altering tristetraprolin expression, stability, and binding to adenine/uridine-rich element. Mol. Cell Biol. 2006, 26, 2399-2407.

121. Brook, M.; Tchen, C.R.; Santalucia, T.; McIlrath, J.; Arthur, J.S.; Saklatvala, J.; Clark, A.R. Posttranslational regulation of tristetraprolin subcellular localization and protein stability by $\mathrm{p} 38$ mitogen-activated protein kinase and extracellular signal-regulated kinase pathways. Mol. Cell Biol. 2006, 26, 2408-2418.

122. Chiba, S.; Tokuhara, M.; Morita, E.H.; Abe, S. TTP at Ser245 phosphorylation by AKT is required for binding to 14-3-3. J. Biochem. 2009, 145, 403-409.

123. Kedar, V.P.; Darby, M.K.; Williams, J.G.; Blackshear, P.J. Phosphorylation of human tristetraprolin in response to its interaction with the $\mathrm{Cbl}$ interacting protein CIN85. PLOS ONE 2010, 5, e9588.

124. Cao, H.; Lin, R. Phosphorylation of recombinant tristetraprolin in vitro. Protein J. 2008, 27, 163-169.

125. Cao, H.; Deterding, L.J.; Venable, J.D.; Kennington, E.A.; Yates, J.R., III; Tomer, K.B.; Blackshear, P.J. Identification of the anti-inflammatory protein tristetraprolin as a hyperphosphorylated protein by mass spectrometry and site-directed mutagenesis. Biochem. J. 2006, 394, 285-297.

126. Arma, A.; Bhat, A.A.; Krishnan, M.; Singh, A.B.; Dhawan, P. Trichostatin-A modulates claudin-1 mRNA stability through the modulation of $\mathrm{Hu}$ antigen $\mathrm{R}$ and tristetraprolin in colon cancer cells. Carcinogenesis 2013, 34, 2610-2621.

127. Molle, C.; Zhang, T.; Ysebrant de Lendonck, L.; Gueydan, C.; Andrianne, M.; Sherer, F.; van Simaeys, G.; Blackshear, P.J.; Leo, O.; Goriely, S. Tristetraprolin regulation of interleukin 23 mRNA stability prevents a spontaneous inflammatory disease. J. Exp. Med. 2013, 210, 1675-1684.

128. Evdokimova, V.; Ruzanov, P.; Anglesio, M.S.; Sorokin, A.V.; Ovchinnikov, L.P.; Buckley, J.; Triche, T.J.; Sonenberg, N.; Sorensen, P.H. Akt-mediated YB-1 phosphorylation activates translation of silent mRNA species. Mol. Cell Biol. 2006, 26, 277-292.

129. Sutherland, B.W.; Kucab, J.; Wu, J.; Lee, C.; Cheang, M.C.; Yorida, E.; Turbin, D.; Dedhar, S.; Nelson, C.; Pollak, M.; et al. Akt phosphorylates the Y-box binding protein 1 at Ser102 located in the cold shock domain and affects the anchorage-independent growth of breast cancer cells. Oncogene 2005, 24, 4281-4292.

130. Coles, L.S.; Lambrusco, L.; Burrows, J.; Hunter, J.; Diamond, P.; Bert, A.G.; Vadas, M.A.; Goodall, G.J. Phosphorylation of cold shock domain/Y-box proteins by ERK2 and GSK3 $\beta$ and repression of the human VEGF promoter. FEBS Lett. 2005, 579, 5372-5378. 
131. Khabar, K.S. Post-transcriptional control during chronic inflammation and cancer: A focus on AU-rich elements. Cell Mol. Life Sci. 2010, 67, 2937-2955.

132. Venigalla, R.K.; Turner, M. RNA-binding proteins as a point of convergence of the PI $3 \mathrm{~K}$ and p38 MAPK pathways. Front Immunol. 2012, doi:10.3389/fimmu.2012.00398.

133. Wilson, G.M.; Lu, J.; Sutphen, K.; Suarez, Y.; Sinha, S.; Brewer, B.; Villanueva-Feliciano, E.C.; Ysla, R.M.; Charles, S.; Brewer, G. Phosphorylation of p40AUF1 regulates binding to A + U-rich mRNA-destabilizing elements and protein-induced changes in ribonucleoprotein structure. J. Biol. Chem. 2003, 278, 33039-33048.

134. Johnson, B.A.; Stehn, J.R.; Yaffe, M.B.; Blackwell, T.K. Cytoplasmic localization of tristetraprolin involves 14-3-3-dependent and -independent mechanisms. J. Biol. Chem. 2002, 277, 18029-18036.

135. Taylor, G.A.; Thompson, M.J.; Lai, W.S.; Blackshear, P.J. Mitogens stimulate the rapid nuclear to cytosolic translocation of tristetraprolin, a potential zinc-finger transcription factor. Mol. Endocrinol. 1996, 10, 140-146.

136. Gringhuis, S.I.; García-Vallejo, J.J.; van Het Hof, B.; van Dijk, W. Convergent actions of I kappa B kinase beta and protein kinase $\mathrm{C}$ delta modulate mRNA stability through phosphorylation of 14-3-3 beta complexed with tristetraprolin. Mol. Cell Biol. 2005, 25, 6454-6463.

137. Sun, L.; Stoecklin, G.; van Way, S.; Hinkovska-Galcheva, V.; Guo, R.F.; Anderson, P.; Shanley, T.P. Tristetraprolin (TTP)-14-3-3 complex formation protects TTP from dephosphorylation by protein phosphatase $2 \mathrm{a}$ and stabilizes tumor necrosis factor-alpha mRNA. J. Biol. Chem. 2007, 282, 3766-3777.

138. Sarkar, B.; Lu, J.Y.; Schneider, R.J. Nuclear import and export functions in the different isoforms of the AUF1/heterogeneous nuclear ribonucleoprotein protein family. J. Biol. Chem. 2003, 278, 20700-20707.

139. Wagner, B.J.; DeMaria, C.T.; Sun, Y.; Wilson, G.M.; Brewer, G. Structure and genomic organization of the human AUF1 gene: Alternative pre-mRNA splicing generates four protein isoforms. Genomics 1998, 48, 195-202.

140. Misquitta, C.M.; Iyer, V.R.; Werstiuk, E.S.; Grover, A.K. The role of 3'-untranslated region (3'-UTR) mediated mRNA stability in cardiovascular pathophysiology. Mol. Cell Biochem. 2001, 224, 53-67.

141. Fellows, A.; Deng, B.; Mierke, D.F.; Robey, R.B.; Nichols, R.C. Peptides modeled on the RGG domain of AUF1/hnRNP-D regulate 3' UTR-dependent gene expression. Int. Immunopharmacol. 2013, 17, 132-141.

142. Li, M.L.; Defren, J.; Brewer, G. Hsp27 and F-box protein $\beta$-TrCP promote degradation of mRNA decay factor AUF1. Mol. Cell Biol. 2013, 33, 2315-2326.

143. Loflin, P.; Chen, C.Y.; Shyu, A.B. Unraveling a cytoplasmic role for hnRNP D in the in vivo mRNA destabilization directed by the AU-rich element. Genes Dev. 1999, 13, 1884-1897.

144. Tolnay, M.; Baranyi, L.; Tsokos, G.C. Heterogeneous nuclear ribonucleoprotein D0 contains transactivator and DNA-binding domains. Biochem. J. 2000, 348, 151-158.

145. Fawal, M.; Armstrong, F.; Ollier, S.; Dupont, H.; Touriol, C.; Monsarrat, B.; Delsol, G.; Payrastre, B.; Morello, D. A "liaison dangereuse" between AUF1/hnRNPD and the oncogenic tyrosine kinase NPM-ALK. Blood 2006, 108, 2780-2788. 
146. Brennan, C.M.; Steitz, J.A. HuR and mRNA stability. Cell Mol. Life Sci. 2001, 58, 266-277.

147. Zou, T.; Liu, L.; Rao, J.N.; Marasa, B.S.; Chen, J.; Xiao, L.; Zhou, H.; Gorospe, M.; Wang, J.Y. Polyamines modulate the subcellular localization of RNA-binding protein HuR through AMP-activated protein kinase-regulated phosphorylation and acetylation of importin alphal. Biochem. J. 2008, 409, 389-398.

148. Winzen, R.; Kracht, M.; Ritter, B.; Wilhelm, A.; Chen, C.Y.; Shyu, A.B.; Müller, M.; Gaestel, M.; Resch, K.; Holtmann, H. The p38 MAP kinase pathway signals for cytokine-induced mRNA stabilization via MAP kinase-activated protein kinase 2 and an AU-rich region-targeted mechanism. EMBO J. 1999, 18, 4969-4980.

149. Ming, X.F.; Stoecklin, G.; Lu, M.; Looser, R.; Moroni, C. Parallel and independent regulation of interleukin-3 mRNA turnover by phosphatidylinositol 3-kinase and p38 mitogen-activated protein kinase. Mol. Cell Biol. 2001, 21, 5778-5789.

150. Wang, W.; Caldwell, M.C.; Lin, S.; Furneaux, H.; Gorospe, M. HuR regulates cyclin A and cyclin B1 mRNA stability during cell proliferation. EMBO J. 2000, 19, 2340-2350.

151. Doller, A.; Pfeilschifter, J.; Eberhardt, W. Signalling pathways regulating nucleo-cytoplasmic shuttling of the mRNA-binding protein HuR. Cell Signal. 2008, 20, 2165-2173.

152. Pascale, A.; Amadio, M.; Scapagnini, G.; Lanni, C.; Racchi, M.; Provenzani, A.; Govoni, S.; Alkon, D.L.; Quattrone, A. Neuronal ELAV proteins enhance mRNA stability by a PKCalpha-dependent pathway. Proc. Natl. Acad. Sci. USA 2005, 102, 12065-12070.

153. Yu, T.X.; Wang, P.Y.; Rao, J.N.; Zou, T.; Liu, L.; Xiao, L.; Gorospe, M.; Wang, J.Y. Chk2-dependent HuR phosphorylation regulates occludin mRNA translation and epithelial barrier function. Nucleic Acids Res. 2011, 39, 8472-8487.

154. Liu, L.; Rao, J.N.; Zou, T.; Xiao, L.; Wang, P.Y.; Turner, D.J.; Gorospe, M.; Wang, J.Y. Polyamines regulate c-Myc translation through Chk2-dependent HuR phosphorylation. Mol. Biol. Cell. 2009, 20, 4885-4898.

155. Briata, P.; Ilengo, C.; Corte, G.; Moroni, C.; Rosenfeld, M.G.; Chen, C.Y.; Gherzi, R. The Wnt/beta-catenin-Pitx2 pathway controls the turnover of Pitx2 and other unstable mRNAs. Mol. Cell. 2003, 12, 1201-1211.

156. Shen, Z.J.; Malter J.S. Direct interaction of phosphorylated AUF1 with ARE mRNA. Department of Pathology, University of Texas Southwestern Medical Center, Dallas, TX, USA. Unpublished work, 2014.

157. Shen, Z.J.; Braun, R.K.; Hu, J.; Xie, Q.; Chu, H.; Love, R.B.; Stodola, L.A.; Rosenthal, L.A.; Szakaly, R.J.; Sorkness, R.L.; et al. Pin1 protein regulates Smad protein signaling and pulmonary fibrosis. J. Biol. Chem. 2012, 287, 23294-23305.

158. Esnault, S.; Rosenthal, L.A.; Shen, Z.J.; Sedgwick, J.B.; Szakaly, R.J.; Sorkness, R.L.; Malter, J.S. A critical role for Pin1 in allergic pulmonary eosinophilia in rats. J. Allergy Clin. Immunol. 2007, 120, 1082-1088.

159. Rajbhandari, P.; Schalper, K.A.; Solodin, N.M.; Ellison-Zelski, S.J.; Ping Lu, K.; Rimm, D.L.; Alarid, E.T. Pin1 modulates ER $\alpha$ levels in breast cancer through inhibition of phosphorylationdependent ubiquitination and degradation. Oncogene 2014, 33, 1438-1447. 
160. Innes, B.T.; Bailey, M.L.; Brandl, C.J.; Shilton, B.H.; Litchfield, D.W. Non-catalytic participation of the Pin1 peptidyl-prolyl isomerase domain in target binding. Front Physiol. 2013, doi:10.3389/fphys.2013.00018.

161. Lu, P.J.; Zhou, X.Z.; Shen, M.; Lu, K.P. Function of WW domains as phosphoserine-or phosphothreonine-binding modules. Science 1999, 283, 1325-1328.

162. Smet, C.; Wieruszeski, J.M.; Buée, L.; Landrieu, I.; Lippens, G. Regulation of Pin1 peptidyl-prolyl cis/trans isomerase activity by its WW binding module on a multi-phosphorylated peptide of Tau protein. FEBS Lett. 2005, 579, 4159-4164.

163. Khanal, P.; Yun, H.J.; Lim, S.C.; Ahn, S.G.; Yoon, H.E.; Kang, K.W.; Hong, R.; Choi, H.S. Proyl isomerase Pin1 facilitates ubiquitin-mediated degradation of cyclin-dependent kinase 10 to induce tamoxifen resistance in breast cancer cells. Oncogene 2012, 31, 3845-3856.

164. Valley, C.C.; Métivier, R.; Solodin, N.M.; Fowler, A.M.; Mashek, M.T.; Hill, L.; Alarid, E.T. Differential regulation of estrogen-inducible proteolysis and transcription by the estrogen receptor alpha N terminus. Mol. Cell Biol. 2005, 25, 5417-5428.

165. Min, S.H.; Lau, A.W.; Lee, T.H.; Inuzuka, H.; Wei, S.; Huang, P.; Shaik, S.; Lee, D.Y.; Finn, G.; Balastik, M.; et al. Negative regulation of the stability and tumor suppressor function of Fbw7 by the Pin1 prolyl isomerase. Mol. Cell. 2012, 46, 771-783.

166. Epis, M.R.; Barker, A.; Giles, K.M.; Beveridge, D.J.; Leedman, P.J. The RNA-binding protein HuR opposes the repression of ERBB-2 gene expression by microRNA miR-331-3p in prostate cancer cells. J. Biol. Chem. 2011, 286, 41442-41454.

167. Bhattacharyya, S.N.; Habermacher, R.; Martine, U.; Closs, E.I.; Filipowicz, W. Stress-induced reversal of microRNA repression and mRNA P-body localization in human cells. Cold Spring Harb. Symp. Quant Biol. 2006, 71, 513-521.

168. Kim, H.H.; Kuwano, Y.; Srikantan, S.; Lee, E.K.; Martindale, J.L.; Gorospe, M. HuR recruits let-7/RISC to repress c-Myc expression. Genes Dev. 2009, 23, 1743-1748.

169. Holbert, M.A.; Sikorski, T.; Carten, J.; Snowflack, D.; Hodawadekar, S.; Marmorstein, R. The human monocytic leukemia zinc finger histone acetyltransferase domain contains DNA-binding activity implicated in chromatin targeting. J. Biol. Chem. 2007, 282, 36603-36613.

170. Ishida, M.; Shimojo, H.; Hayashi, A.; Kawaguchi, R.; Ohtani, Y.; Uegaki, K.; Nishimura, Y.; Nakayama, J. Intrinsic nucleic acid-binding activity of Chpl chromodomain is required for heterochromatic gene silencing. Mol. Cell. 2012, 47, 228-241.

171. Seko, Y.; Cole, S.; Kasprzak, W.; Shapiro, B.A.; Ragheb, J.A. The role of cytokine mRNA stability in the pathogenesis of autoimmune disease. Autoimmun. Rev. 2006, 5, 299-305.

172. Carter, B.Z.; Malter, J.S. Regulation of mRNA stability and its relevance to disease. Lab. Investig. 1991, 65, 610-621.

173. Manganaro, L.; Lusic, M.; Gutierrez, M.I.; Cereseto, A.; Del Sal, G.; Giacca, M. Concerted action of cellular JNK and Pin1 restricts HIV-1 genome integration to activated CD4 ${ }^{+} \mathrm{T}$ lymphocytes. Nat. Med. 2010, 16, 329-333.

174. Saitoh, T.; Tun-Kyi, A.; Ryo, A.; Yamamoto, M.; Finn, G.; Fujita, T.; Akira, S.; Yamamoto, N.; Lu, K.P.; Yamaoka, S. Negative regulation of interferon-regulatory factor 3-dependent innate antiviral response by the prolyl isomerase Pin1. Nat. Immunol. 2006, 7, 598-605. 
175. Lang, R.A.; Metcalf, D.; Cuthbertson, R.A.; Lyons, I.; Stanley, E.; Kelso, A.; Kannourakis, G.; Williamson, D.J.; Klintworth, G.K.; Gonda, T.J.; et al. Transgenic mice expressing a hemopoietic growth factor gene (GM-CSF) develop accumulations of macrophages, blindness, and a fatal syndrome of tissue damage. Cell 1987, 51, 675-686.

176. Biondo, M.; Nasa, Z.; Marshall, A.; Toh, B.H.; Alderuccio, F. Local transgenic expression of granulocyte macrophage-colony stimulating factor initiates autoimmunity. J. Immunol. 2001, 166, 2090-2099.

177. Johnson, G.R.; Gonda, T.J.; Metcalf, D.; Hariharan, I.K.; Cory, S. A lethal myeloproliferative syndrome in mice transplanted with bone marrow cells infected with a retrovirus expressing granulocyte-macrophage colony stimulating factor. EMBO J. 1989, 8, 441-448.

(C) 2015 by the authors; licensee MDPI, Basel, Switzerland. This article is an open access article distributed under the terms and conditions of the Creative Commons Attribution license (http://creativecommons.org/licenses/by/4.0/). 